\title{
The Effect of Commercial Practice Restrictions: The Case of Optometry
}

Deborah Haas-Wilson

Smith College, dhwilson@smith.edu

Follow this and additional works at: https://scholarworks.smith.edu/eco_facpubs

Part of the Economics Commons

\section{Recommended Citation}

Haas-Wilson, Deborah, "The Effect of Commercial Practice Restrictions: The Case of Optometry" (1986). Economics: Faculty Publications, Smith College, Northampton, MA.

https://scholarworks.smith.edu/eco_facpubs/6 


\section{| CHICAgo JOURNALS}

The Effect of Commercial Practice Restrictions: The Case of Optometry

Author(s): Deborah Haas-Wilson

Source: Journal of Law and Economics, Vol. 29, No. 1 (Apr., 1986), pp. 165-186

Published by: The University of Chicago Press

Stable URL: http://www.jstor.org/stable/725407

Accessed: $2 6 \longdiv { / 1 0 / 2 0 0 9 ~ 1 5 : 1 9 }$

Your use of the JSTOR archive indicates your acceptance of JSTOR's Terms and Conditions of Use, available at http://www.jstor.org/page/info/about/policies/terms.jsp. JSTOR's Terms and Conditions of Use provides, in part, that unless you have obtained prior permission, you may not download an entire issue of a journal or multiple copies of articles, and you may use content in the JSTOR archive only for your personal, non-commercial use.

Please contact the publisher regarding any further use of this work. Publisher contact information may be obtained at http://www.jstor.org/action/showPublisher?publisherCode=ucpress.

Each copy of any part of a JSTOR transmission must contain the same copyright notice that appears on the screen or printed page of such transmission.

JSTOR is a not-for-profit service that helps scholars, researchers, and students discover, use, and build upon a wide range of content in a trusted digital archive. We use information technology and tools to increase productivity and facilitate new forms of scholarship. For more information about JSTOR, please contact support@jstor.org.

The University of Chicago Press is collaborating with JSTOR to digitize, preserve and extend access to Journal of Law and Economics. 


\title{
THE EFFECT OF COMMERCIAL PRACTICE RESTRICTIONS: THE CASE OF OPTOMETRY*
}

\author{
DEBORAH HAAS-WILSON \\ Smith College
}

I. INTRODUCTION

\begin{abstract}
C
URRENT regulatory policy toward the business practices of optometrists is based on the assumption that the market fails because (1) consumers are faced with the dilemma of selecting an optometrist without the benefit of full information on the quality of goods and services provided by available optometrists and (2) some optometrists exploit this asymmetric information between consumers and sellers by lowering quality. This assumption has led to the inference that regulation of optometrists' production and information dissemination processes is necessary to protect consumers from their own purchase decisions and from unfair seller behavior. Examples of current commercial practice regulations include state restrictions on (1) the employment of optometrists by nonprofessional corporations, ${ }^{1}(2)$ the permissible locations of optometrists' offices, (3) the operation of multiple offices by optometrists, and (4) the use of trade names by optometrists employed by nonprofessional corporations.

Although there is theoretical support for the argument that asymmetric consumer information about product quality will result in market failure ${ }^{2}$
\end{abstract}

* I would like to thank Dennis Carlton, Richard Gilbert, Theodore Keeler, John Kushman, Richard Scheffler, Lawrence Wilson, and an anonymous referee for helpful comments. Also I would like to thank the U.S. Federal Trade Commission for generously providing part of the data base.

${ }^{1}$ Professional corporations differ from nonprofessional corporations in that professional corporation law requires each stockholder of a professional corporation to be a licensed member of the profession for which the corporation is organized to practice. See, generally, Seymour L. Coblens, Optometry and the Law (1976).

${ }^{2}$ For exam $\rightarrow$ George A. Akerlof, The Market for "Lemons": Quality Uncertainty and the Market Mechanism, 84 Q. J. Econ. $488\left(19^{\circ} \rightarrow\right.$ Hayne E. Leland, Quacks, Lemons, and Licensing: A Theory of Minimum Quality Standards, 87 J. Pol. Econ. $1328\left(19^{\circ} \rightarrow\right.$ Richard

[Journal of Law \& Economics, vol. XXIX (April 1986)]

(C) 1986 by The University of Chicago. All rights reserved. $0022-2186 / 86 / 2901-0007 \$ 01.50$ 
the commercial practice restrictions imposed on optometrists are increasingly being perceived as a means to serve some optometrists' selfinterests rather than the "public interest." The Federal Trade Commission (FTC) has argued that state restrictions on employment, location, branch offices, and trade names serve some optometrists' self-interests by restricting the growth of high-volume, chain vision-care outlets. ${ }^{3}$ Further restrictions on optometrists' advertising have been shown to increase the price of ophthalmic goods and services ${ }^{4}$ and to increase price without increasing quality. ${ }^{5}$

While a large body of empirical evidence exists on the effect of advertising restrictions, little empirical evidence exists on the effects of other commercial practice restrictions, such as the employment, location, branch office, and trade name restrictions. Benham and Benham and the FTC estimated the effect of the degree of professional control $;{ }^{6}$ however, neither study measured professional control on the basis of the extent of state commercial practice restrictions. Benham and Benham measured professional control as (1) the proportion of optometrists within each state belonging to the American Optometric Association (AOA), (2) the market share of large chain optical firms, and (3) the assessment of five representatives of large chain optical firms of the "difficulty which a commercial firm has entering and operating in a state for reasons other than competition with existing commercial firms." 7 The FTC measured professional control as the presence or absence of chain optical firms employing optometrists and as the type of media advertising observed in the area. ${ }^{8}$

Both the Benhams' and the FTC's studies are subject to the problem of

Schmalensee, A Model of Advertising and Product Quality, 86 J. Pol. Econ. 485 (1978);

$\rightarrow$ Dennis E. Smallwood \& John Conlisk, Product Quality in Markets Where Consumers Are Imperfectly Informed, 93 Q. J. Econ. 1 (1979); and Charles Stuart, Consumer Protection in Markets with Informationally Weak Buyers, 12 Bell J. Econ. 562 (1981).

${ }^{3}$ Federal Trade Commission, State Restrictions on Vision Care Providers: The Effects on Consumers ("Eyeglasses II") (July 1980).

${ }^{4}$ For exam $\rightarrow \rightarrow$ Lee Benham, The Effect of Advertising on the Price of Eyeglasses, $15 \mathrm{~J}$. Law \& Econ. 337 (1972).

${ }^{5}$ For example, Federal Trade Commission, Effects of Restrictions on Advertising and Commercial Practice in the Professions: The Case of Optometry (September $19 i \rightarrow$ Roger Feldman \& James W. Begun, The Effects of Advertising: Lessons from Optometry, $13 \mathrm{~J}$. Hum. Resources 247 (Suppl. 1978); $: \rightarrow$ John E. Kwoka, Advertising and the Price and Quality of Optometric Services, 74 Am. Econ. Rev. 211 (1984).

$\rightarrow$ Lee Benham \& Alexandra Benham, Regulating through the Professions: A Perspective on Information Control, 18 J. Law \& Econ. 421 (1975); and Federal Trade Commission, supra note 5 .

${ }^{7}$ Benham \& Benham, supra note 6, at 426-27.

${ }^{8}$ Federal Trade Commission, supra note 5, at 2. 
TABLE 1

Classification Problems in Earlier Studies

\begin{tabular}{|c|c|c|c|}
\hline $\begin{array}{c}\text { Standard } \\
\text { Metropolitan } \\
\text { Statistical } \\
\text { Areas }\end{array}$ & $\begin{array}{c}\text { FTC } \\
\text { Classification of } \\
\text { Restrictiveness* }\end{array}$ & $\begin{array}{c}\text { Benham \& } \\
\text { Benham } \\
\text { Classification } \dagger\end{array}$ & $\begin{array}{c}\text { Number of Pearle } \\
\text { Vision Center/ } \\
\text { Texas State } \\
\text { Optical Stores } \\
\text { by State, } 1983\end{array}$ \\
\hline Knoxville, Tenn. & Most & Restrictive & 27 \\
\hline Little Rock, Ark. & Most & Restrictive & 13 \\
\hline Providence, R.I. & Most & Not included & 2 \\
\hline Columbia, S.C. & Next most & Restrictive & 15 \\
\hline Greensboro, N.C. & Next most & Restrictive & 18 \\
\hline Milwaukee & Next most & Other & 11 \\
\hline Portland, Or. & Next least & Other & 0 \\
\hline Columbus, Ohio & Next least & Nonrestrictive & 24 \\
\hline Baltimore & Least & Nonrestrictive & 34 \\
\hline Washington, D.C. & Least & Nonrestrictive & 1 \\
\hline Seattle & Least & Other & 5 \\
\hline Minneapolis & Least & Nonrestrictive & 20 \\
\hline
\end{tabular}

Sources.-Federal Trade Commission, Effects of Restrictions on Advertising and Commercial Practice in the Professions: The Case of Optometry 41, table 2-1 (September 1980). Lee Benham \& Alexandra Benham, Regulating through the Professions: A Perspective on Information Control, $18 \mathrm{~J}$. Law \& Econ. 421, 426-27 n.14 (1975). Pearle Health Services, Inc., Prospectus 12 (September 16, 1983).

* A Standard Metropolitan Statistical Area (SMSA) was classified as "most restrictive" if chain firms and advertising were not observed, as "next most restrictive" if nonprice advertising of eyeglasses was observed, as "next least restrictive" if nonprice advertising of eyeglasses and exams and chain firms were observed, and as "least restrictive" if price advertising of eyeglasses and chain firms were observed.

† A state was classified as "restrictive" if at least one representative of the commercial firms surveyed included it among the most difficult states and as "nonrestrictive" if at least one respondent included it among the least difficult states. The remaining states were designated as "other."

errors in variables. Certain states that are classified laissez-faire may actually be restrictive, and certain states classified as highly restrictive may be less restrictive. ${ }^{9}$ Table 1 shows that states included by the Benhams in the most restrictive category are not included in the FTC's most restrictive category. And each study classifies states as least restrictive that the other study does not. ${ }^{10}$ Further, there is a weak relationship between both the Benhams' and the FTC's classifications of markets by

${ }^{9}$ For example, the FTC classified Seattle as least restrictive, yet optometrists in Washington State are subject to three commercial practice restrictions, namely, the employment restriction by court order, the location restriction by state board regulation, and the trade name restriction by statute. Little Rock, Arkansas, was classified as rnost restrictive, yet optometrists in Arkansas are subject to only the employment restriction. Benham \& Benham, supra note 6, at 426.

${ }^{10}$ The Benhams mention in a footnote that even the five representatives of the large commercial firms did not always agree on which states should be included in the restrictive and nonrestrictive categories. Benham \& Benham, supra note 6 , at 426. 
restrictiveness and the presence of commercial optical firms, measured as the number of retail optical stores operated or franchised by Pearle Health Services, the largest retailer of ophthalmic goods and services in the United States. ${ }^{11}$

This study does not attempt to classify states by restrictiveness and, as a result, is not plagued by a similar errors-in-variables problem. This paper estimates the effect of the presence of specific commercial practice restrictions. The restriction is present in a state if it is imposed by state statute, board of optometry regulation, court decision, or attorney general opinion. ${ }^{12}$ The effects of the restrictions will depend on enforcement, but measurement of the presence of restrictions by state does not. ${ }^{13}$

Accordingly, after a brief description of the market for ophthalmic goods and services and an analysis of the commercial practice restrictions, this paper presents an econometric study of the economic effect of the employment, location, branch office, and trade name restrictions. In particular, the effects of these restrictions on the price and quality of eye examinations and eyeglasses provided by optometrists are analyzed in markets characterized by different levels of consumer information and entry barriers. Further, this research provides a preliminary test of a recent amendment to the economic theory of regulation-that the regulatory process can be used as a strategic weapon by subgroups of firms within an industry against other subgroups within that industry.

\section{The Market for Ophthalmic Goods and Services}

Most optometrists are self-employed; however, the market share of layemployed optometrists (optometrists employed by drug and department stores and other nonprofessional optical firms) is increasing. In 1977, 80

11 This is due in part to the difference between the FTC's classification criteria, the presence of optical firms employing optometrists, and Pearle Health Service's marketing strategy. "The Companies' marketing strategy is premised upon the availability of optometric services at or near the location of the retail optical store. . . In nine states of the United States, the Company employs optometrists to provide eye examinations and related services. In most other jurisdictions in which the Company operates stores, the Company leases space adjacent to the retail optical store to an optometrist who provides these services.' Pearle Health Services, Inc., Prospectus, 11-13 (September 16, 1983).

12 Certain state optometric associations' rules of practice and codes of ethics also suggest ways to establish and maintain one's practice; however, the private association's only enforcement mechanism is expulsion from membership. Many optometrists choose not to belong in the first place.

${ }^{13}$ The commercial practice restriction data were obtained from the July 1980 FTC report ("Eyeglasses II") and then cross-checked with the state optometry laws listed in the 1978 Blue Book of Optometrists. A further check was made by writing to each state board of optometry and state optometric association. 
percent of all optometrists were self-employed, 4 percent were employed by professional corporations, 2 percent by nonprofessional corporations, and 14 percent by the government, other optometrists, or ophthalmologists. ${ }^{14}$ Between 1973 and 1984 the market share of optical chain firms increased from 3 to 15 percent in the market for eye examinations and from 7 to 20 percent in the market for eye wear. ${ }^{15}$

Many self-employed optometrists and optometrists employed by professional corporations oppose the provision of ophthalmic services by nonprofessional optical firms. Lay-employed optometrists, opponents argue, may employ a variety of cost-cutting techniques, such as providing brief and inadequate eye examinations, in order to increase profits. Further, lay-employed optometrists practicing under a trade name lack personal accountability and the need to maintain a personal reputation for high-quality service. Opponents also argue that the management of nonprofessional optical firms may interfere in the doctor-patient relationship and with professional judgments concerning patient welfare. Thus opponents argue that commercial practice restrictions are necessary to prevent lay-employed optometrists from increasing their market share by selling services at lower prices and substituting low-for high-quality care without consumer recognition of this change in quality. ${ }^{16}$

\section{Commercial Practice Restrictions in Optometry}

Optometric jurisprudence is state oriented. All states and the District of Columbia require the licensure of optometrists. The state licensing statutes define the functions of the optometric profession and limit the performance of these functions to licensed persons. The state licensing statutes also provide for the establishment of state boards of examiners in optometry to perform licensing and regulatory functions. The state boards are authorized to issue rules and regulations, to define requirements for licensure, and to discipline persons who have violated the licensing statutes. Where state laws do not delineate specific grounds for license suspension or revocation, the state boards are usually empowered to define "unprofessional" or "unethical" conduct, which is grounds for license suspension or revocation in most states.

This state-by-state self-regulation has resulted in wide cross-sectional variation in the type of commercial practice restrictions placed on op-

\footnotetext{
${ }^{14}$ U.S. Dep't of Health, Education, \& Welfare, Bureau of Health Management, Supply of Optometrists in the United States, Current and Future 16 (October 1978).

${ }_{15}$ Pearle Health Services, Inc., Annual Report 4 (1983).

16 See Federal Trade Commission, supra note 3, at 29-35.
} 
tometrists. Table 2 shows that, in 1980, state laws, regulations, attorney general opinions, and court decisions existed in thirty-seven states concerning the employment of optometrists by nonprofessional firms, in twenty-eight states concerning the permissible locations of optometrists' offices, in twenty-two states concerning the number of branch offices an optometrist may operate, and in forty-one states concerning the ability of optometrists employed by nonprofessional firms to practice under a trade name.

The employment restrictions usually provide that it is unprofessional conduct or an illegal practice for an optometrist to accept employment from an unlicensed person or firm. For example, the provision in the North Carolina statute reads: "[A]nd it shall be likewise unlawful for any corporation, lay body, organization, group, or lay individual to engage, or undertake to engage, in the practice of optometry through means of engaging the services, upon a salary or commission basis, of one licensed to practice optometry or medicine in any of its branches in this State. Likewise, it shall be unlawful for any optometrist licensed under the provisions of this Article to undertake to engage in the practices of optometry as a salaried or commissioned employee of any corporation, lay body, organization, group, or lay individual.,"17

Restrictions on location usually provide that it is unprofessional conduct or an illegal practice to work in an office not devoted exclusively to the practice of optometry or some other health care profession or in which materials are displayed pertaining to a commercial undertaking not related to the practice of optometry. For example, the provision in the South Carolina statute reads: "Any person registered as provided for in this chapter may have his certificate of registration revoked or suspended by the board for . . . [f]ailure to have their offices for the practice of optometry, . . . in offices separate and distinct from any business organization, with doors leading directly to the street, or public halls leading directly to the street. They shall not practice or operate in or on premises where any material other than those necessary to render their services are dispensed to the public." 18

Branch office restrictions usually set a maximum number of branch offices an optometrist may operate or require the optometrist to be in personal attendance a certain proportion of the time the office is open to the public. The California statute reads: "Nothing in this chapter shall prevent an optometrist from owning, maintaining or operating more than one branch office if he is in personal attendance at each of his offices fifty

${ }^{17}$ N.C. Admin. Code, $\$ 90-125$.

18 S.C. Code Ann., No. 56-1077. 
TABLE 2

Commercial Practice Restrictions by State, 1980

\begin{tabular}{|c|c|c|c|c|}
\hline State & $\begin{array}{l}\text { Employment } \\
\text { Restriction }\end{array}$ & $\begin{array}{l}\text { Location } \\
\text { Restriction }\end{array}$ & $\begin{array}{l}\text { Branch Office } \\
\text { Restriction }\end{array}$ & $\begin{array}{l}\text { Trade Name } \\
\text { Restriction }\end{array}$ \\
\hline Alabama & $\mathrm{S}^{*}$ & & $\mathrm{~S}$ & $S$ \\
\hline Alaska & $\mathrm{R}$ & $\mathrm{R}$ & $S, R$ & $\mathrm{R}$ \\
\hline Arizona & $\mathbf{R}$ & $\ldots$ & $\mathrm{R}$ & $\mathrm{R}, \mathrm{S}^{*}$ \\
\hline Arkansas & $\mathrm{S}$ & $\ldots$ & $\ldots$ & $\ldots$ \\
\hline California & $S$ & $\ldots$ & S & $\mathrm{R}, \mathrm{S}^{*}$ \\
\hline Colorado & $S$ & $\mathrm{R}$ & $\ldots$ & $\mathrm{R}$ \\
\hline Connecticut & $S$ & $\mathrm{~S}$ & $\mathbf{R}$ & $\ldots$ \\
\hline Delaware & $\mathrm{S}, \mathrm{R}$ & $\mathrm{S}, \mathrm{R}$ & $\ldots$ & $\mathbf{R}$ \\
\hline District of Columbia & & $\ldots$ & $\ldots$ & \\
\hline Florida & $S, R$ & $\mathbf{R}$ & $\mathbf{R}$ & $S, R$ \\
\hline Georgia & $\ldots$ & $\mathbf{R}$ & $\mathrm{R}, \mathrm{C}$ & $\mathbf{R}$ \\
\hline Hawaii & $\mathrm{S}$ & $\mathrm{S}$ & $\ldots$ & $\mathrm{S}$ \\
\hline Idaho & $S, R$ & $\mathbf{R}$ & $\mathrm{R}$ & $\mathrm{R}, \mathrm{S}^{*}$ \\
\hline Illinois & $\ldots$ & $\ldots$ & $\ldots$ & $\mathrm{S}$ \\
\hline Indiana & $\mathrm{S}$ & $\ldots$ & $\ldots$ & $\mathbf{R}$ \\
\hline Iowa & $\mathrm{C}$ & $\ldots$ & $\ldots$ & $\mathrm{S}^{*}$ \\
\hline Kansas & $\mathrm{S}, \mathrm{R}, \mathrm{C}$ & $\ldots$ & $\cdots$ & S, R \\
\hline Kentucky & $\mathrm{R}, \mathrm{C}$ & $\ldots$ & $\mathrm{S}, \mathrm{R}$ & S \\
\hline Louisiana & C & $\ldots$ & $\ldots$ & $\ldots$ \\
\hline Maine & $\mathrm{S}$ & $\mathbf{S}$ & $\mathbf{S}$ & $\mathrm{S}$ \\
\hline Maryland & $\mathrm{S}^{*}$ & $\ldots$ & & \\
\hline Massachusetts & S & $\mathbf{R}$ & $\mathrm{R}, \mathrm{A}$ & $S, R$ \\
\hline Michigan & $\mathrm{S}^{*}$ & $\ldots$ & $\ldots$ & $\mathrm{R}$ \\
\hline Minnesota & $A, S^{*}$ & $\ldots$ & $\ldots$ & \\
\hline Mississippi & $\mathrm{R}, \mathrm{C}, \mathrm{A}$ & $\mathbf{R}$ & $\mathrm{R}$ & $\mathrm{R}$ \\
\hline Missouri & $\ldots$ & $\mathbf{R}$ & $\ldots$ & $\mathbf{S}$ \\
\hline Montana & $\mathrm{S}$ & $\mathbf{R}$ & $\ldots$ & $\mathrm{R}, \mathrm{S}^{*}$ \\
\hline Nebraska & & & $\ldots$ & $\ldots$ \\
\hline Nevada & $\mathrm{S}$ & $S, R$ & $\ldots$ & $\mathrm{R}$ \\
\hline New Hampshire & $\mathbf{S}$ & $\mathbf{R}$ & $\ldots$ & $\ldots$ \\
\hline New Jersey & $\mathrm{S}, \mathrm{R}$ & $\mathrm{S}$ & C & $\mathrm{S}$ \\
\hline New Mexico & $\mathrm{S}^{*}$ & $\ldots$ & $\ldots$ & $\mathrm{S}$ \\
\hline New York & $\mathrm{C}$ & $\ldots$ & $\ldots$ & $\mathbf{R}$ \\
\hline North Carolina & $\mathrm{S}$ & $\mathrm{R}$ & $\mathbf{R}$ & $\mathrm{S}$ \\
\hline North Dakota & $\mathrm{S}$ & $\ldots$ & $\ldots$ & $\mathbf{R}$ \\
\hline Ohio & $\mathrm{R}, \mathrm{C}$ & $\ldots$ & $\mathrm{A}$ & $\mathbf{R}$ \\
\hline Oklahoma & $\mathrm{S}$ & $S, R$ & $\mathbf{R}$ & $\mathrm{S}$ \\
\hline Oregon & $\ldots$ & $\ldots$ & $\mathbf{R}$ & $\mathrm{S}^{*}$ \\
\hline Pennsylvania & $\mathrm{R}$ & $\mathrm{R}$ & $\mathrm{R}, \mathrm{S}^{*}$ & $\mathbf{R}$ \\
\hline Rhode Island & $\mathrm{S}$ & S & & $\mathrm{S}, \mathrm{R}$ \\
\hline South Carolina & & $S, R$ & $\mathbf{R}$ & $\mathrm{S}, \mathrm{R}$ \\
\hline South Dakota & $\mathrm{S}, \mathrm{S}^{*}$ & $\mathrm{R}$ & & S, R \\
\hline Tennessee & $\mathrm{S}$ & $\mathrm{S}$ & $\mathrm{S}$ & $\mathrm{S}$ \\
\hline Texas & $\mathrm{S}^{*}$ & $S$ & $\mathrm{~S}$ & $\mathrm{~S}$ \\
\hline Utah & $\mathrm{C}$ & $\mathrm{R}$ & $\ldots$ & $\mathrm{S}$ \\
\hline Vermont & A & $\ldots$ & $\mathrm{S}$ & $\mathrm{R}, \mathrm{S}^{*}$ \\
\hline Virginia & $\mathrm{S}, \mathrm{R}$ & $\mathrm{S}$ & $\ldots$ & $\mathrm{S}, \mathrm{R}$ \\
\hline Washington & $\mathrm{C}$ & $\mathrm{R}$ & $\ldots$ & $\mathrm{S}^{*}$ \\
\hline West Virginia & $\mathrm{R}, \mathrm{S}$ & $\mathrm{S}$ & $\ldots$ & $\mathrm{S}, \mathrm{R}$ \\
\hline Wisconsin & $\mathrm{S}^{*}$ & $\ldots$ & $\ldots$ & $\ldots$ \\
\hline Wyoming & $\mathrm{S}^{*}$ & $\cdots$ & $\ldots$ & $\ldots$ \\
\hline
\end{tabular}

Source.-Federal Trade Commission, State Restrictions on Vision Care Providers: The Effects on Consumers ("Eyeglasses II") 28 (July 1980).

NoTE. $-\mathrm{C}=$ court decision, $\mathrm{S}=$ statutory restriction, $\mathrm{S}^{*}=$ ambiguous statute, $\mathrm{A}=$ attorney general opinion, and $\mathrm{R}=$ state board regulation. 
percent $(50 \%)$ of the time during which such office is open for the practice of optometry." 19

Trade name restrictions usually provide that an optometrist's license to practice may be revoked or suspended for practicing under a name other than his or her own name or under a false or assumed name. However, trade name restrictions

generally do not prevent an optometrist from working for another optometrist and holding him or herself out under the name of the professional corporation. Thus, these restrictions have a distinct discriminatory impact on non-professional corporations. (The discriminatory impact here is not that a professional corporation is able to use a traditional trade name but rather that an individual optometrist can hold him or herself out under a firm name which does not contain his or her individual name so long as that firm is a professional corporation or the name of a licensed optometrist who employs that individual optometrist. $)^{20}$

The existence of commercial practice restrictions in the market for ophthalmic services is consistent with the economic theory of regulation and with recent literature on strategic use of the regulatory process by subgroups of firms within an industry. According to the economic theory of regulation, regulation can be used as a device for transferring income from groups with less political power to groups with more, usually from consumers to the politically powerful regulated industry. ${ }^{21}$ Firms in the regulated industry are assumed to be homogeneous and therefore equally benefited by the regulation and equally interested in promoting the regulation.

Recently, the economic theory of regulation has been extended to include heterogeneous firms and thus the idea that regulations impose different benefits and costs on firms within the industry. ${ }^{22}$ Assuming that heterogeneous firms form subgroups,$^{23}$ regulation can be viewed as a

19 Cal. [Bus. \& Prof.] Code $§ 3007$ (i) (Deering).

${ }^{20}$ Federal Trade Commission, supra note 3, at 23-24.

$21: \rightarrow$ Sam Peltzman, Toward a More General Theory of Regulation, 19 J. Law \& Econ. $211\left(19^{*} \rightarrow\right.$ Richard A. Posner, Theories of Economic Regulation, 5 Bell J. Econ. \& Mgmt. Sci. 335 (1974); $\rightarrow$ George J. Stigler, The Theory of Economic Regulation, 2 Bell J. Econ. \& Mgmt. Sci. 3 (1971).

$22 \rightarrow$ Michael T. Maloney \& Robert E. McCormick, A Positive Theory of Environmental Quality Regulation, 25 J. Law \& Econ. 99 (1982); Sharon Oster, The Strategic Use of Regulatory Investment by Industry Sub-groups, 20 Econ. Inquiry 604 (1982); $\rightarrow$ Steven C. Salop \& David T. Scheffman, Raising Rivals' Costs, 73 Am. Econ. Rev. 267 (1983).

${ }^{23}$ See Richard E. Caves \& Michael E. Porter, From Entry Barriers to Mobility Barriers: Conjectural Decisions and Contrived Deterrence to New Competition, 91 Q. J. Econ. 421 $\left(19^{\prime} \rightarrow\right.$ Howard H. Newman, Strategic Groups and the Structure-Performance Relationship, 60 Rev. Econ. \& Stat. 417 (1978); $\rightarrow$ Michael E. Porter, The Structure within Industries and Companies' Performance, 61 Rev. Econ. \& Stat. 214 (1979). 
device for transferring income from subgroups of firms with less political power to those with more. Politically powerful firms can use the regulatory process as a strategic weapon against other groups of firms within the industry. Oster wrote, "As long as there is some initial difference among firms in an industry, different firms in that industry may push for regulations which increase the relative rate of return to their peculiar characteristics. . . . [T] he firm may even encourage a regulation which lowers its short-term profits if that regulation simultaneously reduces the ability of its rival to compete effectively." 24

Salop and Scheffman make a more general argument and mention regulation as one way to increase rivals' costs: "It is better to compete against high-cost firms than low-cost ones. Thus, raising rivals' costs can be profitable even if the rival does not exit from the market. . . . A highercost rival quickly reduces output, allowing the predator to immediately raise price or market share. "25

Strategic use of the regulatory process is quite possible in the ophthalmic industry. Optometrists regulate themselves, ${ }^{26}$ and the optometrists appointed to the state regulatory boards are not appointed at random. Board members in forty-six states are appointed by the governor from lists of optometrists who have practiced optometry in the state for a specified number of years. In sixteen states, the optometry statutes designate membership in the state optometric association as a prerequisite for appointment, or they require the governor to make appointments from lists submitted by the state optometric association. ${ }^{27}$ Further, the industry consists of differentiated subgroups of firms. Size, marketing strategy, and level of vertical integration differentiate self-employed optometrists from lay-employed optometrists.

\section{The Economic Effect of Commercial Practice Restrictions}

The employment restriction prevents nonprofessional optical firms from employing optometrists and therefore from selling eye examinations and eyeglass prescriptions (that is, offering the one-stop service of dis-

${ }^{24}$ Oster, supra note 22 , at 606.

25 Salop \& Scheffman, supra note 22, at 267.

26 The state optometric boards are composed entirely of optometrists in twenty-six states and the District of Columbia: twelve states require only one lay member, eleven states require only two lay members, and California requires three lay members on the board. Council of State Governments, Health Licensure Boards: Public Membership (1981), at table 1.

27 Federal Trade Commission, Staff Report on Advertising of Ophthalmic Goods and Services and Proposed Trade Regulation Rule (16 CFR Part 456) 34-35 (May 1977). 
pensing optometrists). To the extent that there are economies of scope in the joint production of eye examinations and eyeglasses, the employment restriction forces nonprofessional optical firms to incur the higher cost of producing eyeglasses alone. Thus the employment restriction may deter entry by potential nonprofessional optical firms. However, the employment restriction does not prevent the nonprofessional firm from locating close to an optometrist.

The trade name restriction prevents lay-employed optometrists from including trade names in their advertising. Since consumers can use trade names as a substitute for search or as an aid in processing information about different sellers, the trade name restriction decreases the effectiveness of advertising by nonprofessional optical firms. This may reduce the ability of nonprofessional optical firms to attract new customers and realize scale economies. Like the employment restriction, the trade name restriction may also deter entry by potential nonprofessional optical firms.

The location restriction prevents self-employed and lay-employed optometrists from locating in high-traffic, high-visibility areas such as shopping centers and department stores. This reduces the ability of all optometrists to develop high-volume practices and realize economies of scale. Lay-employed optometrists, however, tend to rely more heavily than self-employed optometrists on convenient locations to attract customers. ${ }^{28}$ Therefore, lay-employed optometrists are more likely to be constrained by the location restriction.

The branch office restriction prevents self-employed and lay-employed optometrists from expanding their practices by opening new offices. To the extent the branch office regulation is binding, optometrists are prevented from utilizing the cost-minimizing combination of inputs. With data from the dental industry, DeVany, Gramm, Saving, and Smithson ${ }^{29}$ show that input regulation increases the ratio of unrestricted to restricted inputs.

The preceding discussion focuses on the commercial practice restrictions' effects on self- and lay-employed optometrists' production costs. Two of the four restrictions, the employment and trade name restrictions, may increase the costs of production for lay-employed optometrists. The

${ }^{28}$ Support for this suggestion is found in the Prospectus of Pearle Health Services, Inc. "They [retail stores] are generally located in high traffic areas convenient to customers, typically in shopping malls, strip shopping centers or freestanding buildings in major shopping areas." Pearle Health Services, Inc., supra note 11 at 11.

${ }^{29}$ Arthur S. DeVany, Wendy L. Gramm, Thomas R. Saving, \& Charles W. Smithson, The Impact of Input Regulation: The Case of the U.S. Dental Industry, 25 J. Law \& Econ. 367 (1982). 
location and branch office restrictions may increase the costs of production for self-employed and lay-employed optometrists; however, it can be argued that the location and branch office restrictions differentially damage lay-employed optometrists. In addition, the analysis suggests that the restrictions may deter entry by nonprofessional optical firms. ${ }^{30}$ The expected result, if this is true, is higher prices.

The hypothesis to be tested, then, is that the commercial practice restrictions have tended to increase eye examination and eyeglass prices. However, the major justification for the restrictions is elimination of lowquality services. Accordingly, the empirical analysis also examines the effect of the restrictions on quality. A hedonic regression is estimated to test the effects of the restrictions on quality-adjusted price. The qualityadjusted price is defined as the price of an eye examination and pair of eyeglasses of a given quality and is revealed to consumers from observed prices of eye examinations and eyeglasses and the level of quality associated with them.

\section{THE Model}

When information is costly, the relevant market structure is monopolistic competition rather than perfect competition. ${ }^{31}$ Accordingly, the ophthalmic industry is modeled as a monopolistically competitive industry. ${ }^{32}$

Assuming optometrists choose price and quality jointly, the qualityadjusted price, $\mathrm{QUALP}_{j}$, charged by optometrist $j$ is a function of optometrist $j$ 's marginal cost, $\mathrm{MC}_{j}$, and price elasticity of demand, $e_{j}$ :

$$
\begin{aligned}
\mathrm{QUALP}_{j}= & f \mathrm{MC}_{j}(\mathrm{INPUT}, \mathrm{R}-\mathrm{EMPLOY}, \mathrm{R}-\mathrm{LOCATE}, \\
& \left.\mathrm{R}-\mathrm{BRANCH}, \mathrm{R}-\mathrm{TN}), e_{j}\left(\mathrm{~A}_{j}, \mathrm{AD}, \mathrm{OPTOM}\right)\right],
\end{aligned}
$$

where INPUT is the price of inputs, R-EMPLOY is the employment restriction, R-LOCATE is the location restriction, R-BRANCH is the branch office restriction, $\mathrm{R}-\mathrm{TN}$ is the trade name restriction, $\mathrm{A}_{j}$ is the

\footnotetext{
${ }^{30}$ Support for this suggestion is found in the Prospectus of Pearie Health Services, Inc. "Management believes that these efforts [Federal Trade Commission proceedings that may result in rules that would preempt restrictions], if successful, would facilitate increased market penetration by the Company in those jurisdictions." Pearle Health Services, Inc. supra note 11 , at 16.

${ }^{31}$ See Steven Salop, Information and Monopolistic Competition, 66 Am. Econ. Rev. 240 (1976).

32 See $a \rightarrow$ Mark V. Pauly \& Mark A. Satterthwaite, The Pricing of Primary Care Physicians' Services: A Test of the Role of Consumer Information, 12 Bell J. Econ. 488 (1981). Pauly and Satterthwaite classify the market for primary medical care as monopolistically competitive "because physicians are price setters and metropolitan areas contain sufficient numbers of competitive physicians to eliminate oligopolistic interactions." Id . at 489.
} 
level of advertising chosen by optometrist $j, \mathrm{AD}$ is competitors' advertising expenditures, and OPTOM is the number of optometrists in the market area. As discussed earlier, R-EMPLOY and R-TN may increase costs for lay-employed optometrists, and R-LOCATE and R-BRANCH may increase costs for self- and lay-employed optometrists. The price elasticity of demand depends on the number of sellers ${ }^{33}$ and the level of advertis-

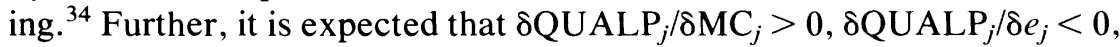
and $\delta \mathrm{MC}_{j} / \delta \mathrm{INPUT}>0$.

Not all optometrists decide to advertise. The advertising choice of optometrist $j$ is assumed to be a function of $\mathrm{QUALP}_{j},{ }^{35}$ competitors' advertising expenditures, ${ }^{36}$ and the trade name restriction:

$$
\mathrm{A}_{j}=g(\mathrm{QUALP}, \mathrm{AD}, \mathrm{R}-\mathrm{TN}) .
$$

The signs of all three variables are ambiguous. For example, R-TN makes advertising by lay-employed optometrists less effective. As a result, the lay-employed optometrist may decide to advertise less or may decide to advertise more to compensate for less-effective advertising messages.

Professionals' location decisions depend on demand for their services, measured as per capita income,${ }^{37}$ state licensure requirements,${ }^{38}$ the supply of competing professionals, ${ }^{39}$ and the regulatory environment ${ }^{40}$ Accordingly, it is assumed that the number of self- and lay-employed optometrists is a function of per capita income, $Y$, the difficulty of the state licensing examination, EXAM, the supply of opticians, OPTIC, and the four commercial practice restrictions:

$$
\begin{aligned}
\text { OPTOM }= & b(Y, \text { EXAM, OPTIC, R-EMPLOY, } \\
& \text { R-LOCATE, R-BRANCH, R-TN }) .
\end{aligned}
$$

${ }^{33}$ Pauly \& Satterthwaite, supra note 32.

${ }^{34}$ See, for example, Phillip Nelson, Advertising as Information, 81 J. Pol. Econ. 729 (1974).

${ }^{35}$ See, for exam $\rightarrow$ Richard E. Kihlstrom \& Michael H. Riordan, Advertising as a Signal, 92 J. Pol. Econ. 427 (1984); and Nelson, supra note 34.

${ }^{36}$ See Michael Waterson, Economic Theory of Industry 131 (1984).

${ }^{37}$ See, for examr $\rightarrow$ L. Benham, A. Maurizi, \& M. W. Reder, Migration, Location and Remuneration of Medical Personnel: Physicians and Dentists, 50 Rev. Econ. \& Stat. 332 (1968); and Alfred Meltzer, Kathryn Langwell, Michael Keane, \& Shelly Nelson, Report on the Geographic Distribution of Vision Care Providers (unpublished report, Applied Management Sciences, Inc., 1983).

${ }^{38}$ See, for example, Benham, Maurizi, \& Reder, supra note 37; and H. E. Frech III, Occupational Licensure and Health Care Productivity: The Issues and the Literature, in Health Manpower and Productivity: The Literature and Required Future Research (John Rafferty ed. 1974).

39 See, for example, Meltzer, Langwell, Keane, \& Nelson, supra note 37.

${ }^{40}$ See, for example, id. 
It is expected that $\delta \mathrm{OPTOM} / \delta Y>0, \delta \mathrm{OPTOM} / \delta \mathrm{OPTIC}<0$, and $\delta \mathrm{OPTOM} / \delta \mathrm{EXAM}<0$. As discussed earlier, R-EMPLOY and R-TN may deter entry by lay-employed optometrists, and R-LOCATE and RBRANCH may deter entry by self- and lay-employed optometrists.

From equations (1), (2) and (3), quality-adjusted price, advertising, and number of optometrists are simultaneously determined by AD and eight exogenous variables. ${ }^{41}$ Competitors' advertising expenditures are endogenous, so an instrumental variable, the presence or absence of media advertising by optometrists in the market, ADVERT, is used in the estimation of equation (4). The state commercial practice restrictions may affect the level of optometrists' advertising expenditures but not whether optometrists choose to advertise in that state. The 1977 Supreme Court ruling in Bates v. State Bar of Arizona allows professionals, regardless of their state's statutes, to advertise. ${ }^{42}$ Accordingly, the effects of the commercial practice restrictions on quality-adjusted price are estimated using the following equation:

$$
\begin{aligned}
\text { QUALP }_{j}= & h(\text { ADVERT, R-EMPLOY, R-LOCATE, } \\
& \text { R-BRANCH, R-TN, EXAM, OPTIC, } \\
& Y, \text { INPUT }) .
\end{aligned}
$$

\section{The Data}

The data sources and the means and standard deviations of the variables are listed in Table 3. Data on the price, quality, and advertising of ophthalmic goods and services were derived from an FTC data set, which includes data on the price and quality of eye examinations and eyeglasses purchased from 280 optometrists in twelve Standard Metropolitan Statistical Areas (SMSAs). ${ }^{43}$ To collect the data the FTC trained nineteen professional survey interviewers to identify the procedures and equipment used in eye examinations ${ }^{44}$ and then sent the interviewers to optometrists'

${ }^{41}$ The state commercial practice restrictions may also be endogenous. For a detailed discussion, see J. Begun, E. Crowe, \& R. Feldman, Occupational Regulation in the States: A Causal Model, 6 J. Health Pol., Pol'y, \& L. 229 (1981). Endogeneity of the restrictions, however, will entail only a small bias in the ordinary least squares estimators if the variance of the errors is small relative to the variance of the regulatory variables. See, for example, G. S. Maddala, Econometrics 153 (1977).

42 Bates v. State Bar of Arizona, 433 U.S. 350 (1977).

${ }^{43}$ Baltimore; Columbia, South Carolina; Columbus, Ohio; Greensboro-HighpointWinston-Salem, North Carolina; Knoxville, Tennessee; Little Rock, Arkansas; Milwaukee; Minneapolis-St. Paul; Portland, Oregon; Providence, Rhode Island; Seattle; and Washington, D.C.

${ }^{44}$ During the training period, the interviewers were also given eye examinations so there would be independent opinions regarding the corrective lenses each subject required for proper vision. 
TABLE 3

Means and Standard Deviations of Variables

\begin{tabular}{|c|c|c|c|}
\hline Variable & Definition & Mean & $\begin{array}{r}\text { Standard } \\
\text { Deviation }\end{array}$ \\
\hline$\overline{\text { PRICE }}$ & $\begin{array}{l}\text { Price of exam and } \\
\text { glasses }\end{array}$ & 79.58 & 13.51 \\
\hline THOROUGH & Thoroughness of exam & 57.56 & 20.96 \\
\hline ACPRESC & $\begin{array}{l}\text { Accuracy of prescrip- } \\
\text { tion }\end{array}$ & .83 & .37 \\
\hline ADVERT & $\begin{array}{l}\text { Media advertising ob- } \\
\text { served }\end{array}$ & .78 & .41 \\
\hline R-TN & Trade name restriction & .52 & .50 \\
\hline R-LOCATE & Location restriction & .38 & .49 \\
\hline R-BRANCH & $\begin{array}{l}\text { Branch office restric- } \\
\text { tion }\end{array}$ & .27 & .45 \\
\hline R-EMPLOY & Employment restriction & .52 & .50 \\
\hline EXAM & $\begin{array}{l}\text { Subjects in licensing } \\
\text { exam }\end{array}$ & 10.53 & 4.05 \\
\hline OPTIC & $\begin{array}{l}\text { Optician/population } \\
\text { ratio }\end{array}$ & 7.12 & 4.42 \\
\hline$Y$ & Per capita income & 8438.78 & 992.28 \\
\hline INPUT & $\begin{array}{l}\text { Hourly wage rate- } \\
\text { manufacturing }\end{array}$ & 4.06 & .64 \\
\hline
\end{tabular}

SourCES.-P, THOROUGH, ACPRESC, and ADVERT computed from data provided by Federal Trade Commission, Effects of Restrictions on Advertising and Commercial Practice in the Professions: The Case of Optometry (September 1980); R-TN, R-LOCATE, R-BRANCH, and R-EMPLOY compiled from data in Federal Trade Commission, State Restrictions on Vision Care Providers: The Effects on Consumers ("Eyeglasses II") 28 (July 1980); EXAM compiled from data in U.S. Department of Health, Education, and Welfare, Report to the Congress: Reimbursement under Part B of Medicare for Certain Services Provided by Optometrists (July 1976); OPTIC from U.S. Department of Health, Education, and Welfare, Opticians Employed in the Health Services, U.S., 1968 (1968); $Y$ from U.S. Department of Commerce, Bureau of Economic Analysis, Survey of Current Business (April 1981); and INPUT from U.S. Department of Commerce, Bureau of the Census, State and Metropolitan Area Data Book (1979).

offices to purchase examinations and eyeglasses in November and December 1977. The interviewers purchased the eye examinations and eyeglasses from 189 self-employed optometrists and ninety-one optometrists employed by drug and department stores and other nonprofessional optical firms.

Local newspapers were scanned from May 1977 to December 1977 to determine the extent of media advertising of eye examinations and eyeglasses in the twelve SMSAs. ${ }^{45}$ Media advertising was observed in nine of the twelve SMSAs. Optometrists were observed advertising on-site with either large signs or window displays in all twelve SMSAs.

Price is measured as the sum of the price of an eye examination and the price of a pair of eyeglasses. The joint price is used because, when the

45 There was no media advertising observed in Knoxville, Tennessee, Little Rock, Arkansas, and Providence, Rhode Island. 
exam and glasses are purchased as a package, it is possible that the itemization of charges is arbitrary.

Quality is measured as the thoroughness of eye examination, THOROUGH, and as the accuracy of the eyeglass prescription, ACPRESC. Thoroughness of the eye examination is an index that measures inputs (procedures performed in the examination) rather than outputs (the optometrist's ability to discover all relevant information about the consumer's eye health). The index, developed by Dr. Kenneth Myers (Director of the Optometric Service, Department of Medicine and Surgery, U.S. Veterans Administration), was constructed by weighting each test or procedure by a value proportional to its importance in the examination.

Accuracy of the prescription is a measure of the clinical judgment of consultants at the State University of New York, College of Optometry, and at the Pennsylvania College of Optometry as to the appropriateness of the prescriptions. The consultants compared their opinions regarding the corrective lenses each subject required for proper vision with the written prescriptions from optometrists and then evaluated the prescriptions for the adequacy with which subjects' visual needs were met.

With respect to the other independent variables, EXAM is measured as the number of subject areas that must be included in the state licensing examination, INPUT is measured as the average SMSA wage rate of production workers in the manufacturing sector, and OPTIC is measured as the ratio of opticians to 100,000 population in the state.

\section{The Empirical Results}

Equation (4) is estimated in double-log form using two specifications and two dependent variables. The results of regressions on price are reported in Table 4, while the results of regressions on quality are reported in Table 5. In the first specification the four commercial practice restrictions are included as dummy variables that equal one if the restriction is present in the state and zero otherwise. In the second specification the restrictions are included as dummy variables, and an index of the degree of state regulation of optometry, REG, is interacted with quality and media advertising. The variable REG is constructed by summing the dummy commercial practice restriction variables by state. This summated scale assigns equal weight to each restriction and ranges from zero to four. Thus the potential interaction between quality choice and the restrictions and the interaction between media advertising and regulatory effect are included in the second specification. ${ }^{46}$

${ }^{46}$ Advertising may permit the realization of production scale economies that might otherwise be unobtainable because of market imperfections or regulation. 
TABLE 4

Regressions on Price, Holding Quality Constant

\begin{tabular}{|c|c|c|c|c|c|}
\hline $\begin{array}{l}\text { Independent } \\
\text { Variable }\end{array}$ & $\mathrm{A}^{*}$ & $\mathrm{~B} \dagger$ & $\mathrm{C} \ddagger$ & $\mathrm{D}^{*}$ & $\mathrm{E} \ddagger$ \\
\hline CONSTANT & $\begin{array}{c}-1.4413 \\
(.98)\end{array}$ & $\begin{array}{c}-.9728 \\
(.62)\end{array}$ & $\begin{array}{c}-13.8777 \\
(3.45)\end{array}$ & $\begin{array}{c}-1.4378 \\
(.98)\end{array}$ & $\begin{array}{c}-14.1398 \\
(3.51)\end{array}$ \\
\hline INPUT & $\begin{array}{l}.8082 \\
(2.51)\end{array}$ & $\begin{array}{l}.9557 \\
(2.79)\end{array}$ & $\begin{array}{l}.7107 \\
(2.23)\end{array}$ & $\begin{array}{l}.8117 \\
(2.52)\end{array}$ & $\begin{array}{l}.7130 \\
(2.24)\end{array}$ \\
\hline$Y$ & $\begin{array}{l}.4888 \\
(2.88)\end{array}$ & $\begin{array}{l}.4123 \\
(2.26)\end{array}$ & $\begin{array}{l}1.8315 \\
(4.18)\end{array}$ & $\begin{array}{l}.4767 \\
(2.80)\end{array}$ & $\begin{array}{l}1.8453 \\
(4.21)\end{array}$ \\
\hline OPTIC & $\begin{array}{l}-.1878 \\
(6.02)\end{array}$ & $\begin{array}{l}-.1814 \\
(5.54)\end{array}$ & $\begin{array}{l}-.5065 \\
(5.02)\end{array}$ & $\begin{array}{l}-.1863 \\
(5.96)\end{array}$ & $\begin{array}{l}-.5116 \\
(5.06)\end{array}$ \\
\hline EXAM & $\begin{array}{l}.1805 \\
(4.80)\end{array}$ & $\begin{array}{l}.1719 \\
(4.21)\end{array}$ & $\begin{array}{l}.3617 \\
(5.48)\end{array}$ & $\begin{array}{l}.1807 \\
(4.80)\end{array}$ & $\begin{array}{l}.3659 \\
(5.54)\end{array}$ \\
\hline ADVERT & $\begin{array}{l}-.3038 \\
(2.59)\end{array}$ & $\begin{array}{l}-.3305 \\
(2.65)\end{array}$ & $\begin{array}{l}.3883 \\
(1.63)\end{array}$ & $\begin{array}{l}-.3046 \\
(2.59)\end{array}$ & $\begin{array}{l}.4022 \\
(1.68)\end{array}$ \\
\hline R-TN & $\begin{array}{l}.0607 \\
(.48)\end{array}$ & $\begin{array}{l}.0182 \\
(.14)\end{array}$ & $\begin{array}{l}.4362 \\
(2.59)\end{array}$ & $\begin{array}{l}.1181 \\
(.83)\end{array}$ & $\begin{array}{l}.5153 \\
(2.82)\end{array}$ \\
\hline R-LOCATE & $\begin{array}{c}-.0015 \\
(.01)\end{array}$ & $\begin{array}{l}.0277 \\
(.24)\end{array}$ & $\begin{array}{l}.0860 \\
(.80)\end{array}$ & $\begin{array}{l}.0536 \\
(.43)\end{array}$ & $\begin{array}{l}.1561 \\
(1.25)\end{array}$ \\
\hline R-BRANCH & $\begin{array}{l}.1545 \\
(1.13)\end{array}$ & $\begin{array}{l}.2177 \\
(1.50)\end{array}$ & $\begin{array}{l}.5687 \\
(3.14)\end{array}$ & $\begin{array}{l}.2080 \\
(1.39)\end{array}$ & $\begin{array}{l}.6621 \\
(3.33)\end{array}$ \\
\hline R-EMPLOY & $\begin{array}{l}-.1592 \\
(4.83)\end{array}$ & $\begin{array}{l}-.1330 \\
(3.62)\end{array}$ & $\begin{array}{l}.1624 \\
(1.59)\end{array}$ & $\begin{array}{l}-.1072 \\
(1.59)\end{array}$ & $\begin{array}{l}.2337 \\
(1.94)\end{array}$ \\
\hline THOROUGH & $\begin{array}{l}.1110 \\
(4.59)\end{array}$ & $\begin{array}{l}.1163 \\
(4.40)\end{array}$ & $\begin{array}{l}.1064 \\
(4.47)\end{array}$ & $\begin{array}{l}.1358 \\
(3.67)\end{array}$ & $\begin{array}{l}.1370 \\
(3.77)\end{array}$ \\
\hline ACPRESC & $\ldots$ & $\begin{array}{l}.0070 \\
(.24)\end{array}$ & $\cdots$ & $\ldots$ & $\ldots$ \\
\hline REG $\times$ ADVERT & .. & $\cdots$ & $\begin{array}{l}-.3830 \\
(3.31)\end{array}$ & $\ldots$ & $\begin{array}{l}-.3912 \\
(3.38)\end{array}$ \\
\hline REG $\times$ THOROUGH & $\ldots$ & $\ldots$ & $\ldots$ & $\begin{array}{c}-.0139 \\
(.88)\end{array}$ & $\begin{array}{l}-.0172 \\
(1.11)\end{array}$ \\
\hline
\end{tabular}

Note. $-t$-statistics are in parentheses.

* $N=280, R^{2}=.23$.

$+N=253, R^{2}=.23$.

$\ddagger N=280, R^{2}=.26$.

Because of the collinearity among the commercial practice restrictions,${ }^{47}$ the individual coefficients cannot be estimated precisely; however, the sum of the coefficients on the regulatory variables can be estimated with considerable accuracy. This sum provides a reliable estimate of the regulatory effect. ${ }^{48}$

${ }^{47}$ High zero-order correlations are a sufficient but not a necessary condition for the existence of multicollinearity. The trade name restriction is highly correlated with the location, the branch office, and the employment restrictions $(r=0.82,0.52$, and 0.54 , respectively).

${ }^{48}$ See Maddala, supra note 41 , at 189. 
TABLE 5

REgRessions ON QUALITY

\begin{tabular}{lcc}
\hline \hline $\begin{array}{l}\text { Independent } \\
\text { Variable }\end{array}$ & $(1)^{*}$ & $(2)^{*}$ \\
\hline CONSTANT & 2.9616 & -7.3147 \\
& $(.93)$ & $.83)$ \\
INPUT & .1384 & -.0037 \\
$Y$ & $(.24)$ & $(.01)$ \\
& .1401 & 1.2572 \\
OPTIC & $(.38)$ & $(1.30)$ \\
& -.1325 & -.3848 \\
EXAM & $(1.93)$ & $(1.81)$ \\
& .0513 & .2000 \\
ADVERT & $(.63)$ & $(1.39)$ \\
& -.2702 & .2865 \\
R-TN & $(1.26)$ & $(.58)$ \\
& -.1656 & .1684 \\
R-LOCATE & $(.67)$ & $(.46)$ \\
R-BRANCH & -.0509 & -.0031 \\
& $(.25)$ & $(.01)$ \\
R-EMPLOY & .0640 & .3900 \\
REG $\times$ ADVERT & $(.25)$ & $(1.08)$ \\
& -.0254 & .2143 \\
& $(.39)$ & $(1.06)$ \\
& $\ldots$ & -.3056 \\
\end{tabular}

Note. $-t$-statistics are in parentheses.

${ }^{*} N=434, R^{2}=.05$.

Results of ordinary least squares regressions that test the effects of the restrictions on price, controlling for differences in quality, are reported in Table 4 . The coefficients on the dummy variables can be interpreted as percentage changes and those on the other variables as elasticities. Regression A and regressions $\mathrm{C}-\mathrm{E}$ include one measure of quality, THOROUGH, while regression $\mathrm{B}$ includes two quality measures, THOROUGH and ACPRESC. Further, regression $\mathrm{C}$ allows for an interaction between the degree of state regulation of optometry and media advertising by optometrists; regression D allows for an interaction between the degree of state regulation of optometry and optometrists' quality decisions; and regression $\mathrm{E}$ allows for both interactions.

The results are consistent with the hypothesis that state commercial practice restrictions increase the price of ophthalmic goods and services, holding quality constant. The sum of the coefficients on the regulatory variables in regression A suggests a positive 5.5 percent difference in the price of an eye examination and pair of eyeglasses in fully regulated versus nonregulated states. Similarly, the summed coefficients for regres- 
sions B-E resulted in positive $13.1,7.3,5.1$, and 7.0 percent differences, respectively, in fully regulated states. In all five regressions the hypothesis that the effect of the commercial practice regulations is equal to zero can be rejected at the 1 percent level of significance $(F=8.14,7.52$, $11.18,8.33$, and 11.50 , respectively).

With respect to the relationship between price and quality, the price of an eye examination and a pair of eyeglasses increases with the thoroughness of the eye examination but not with the accuracy of the eyeglass prescription. A 1 percent increase in the thoroughness of the eye examination results in a $0.11-0.12$ percent increase in the price of an eye examination and pair of eyeglasses. The coefficient on ACPRESC, however, is not significantly different from zero. This suggests that prices convey information on one aspect of product quality, thoroughness of the examination, but prices do not convey information on a second aspect of quality, prescription accuracy. A possible explanation of this is that consumers can assess thoroughness but not prescription accuracy.

In all five regressions media advertising by optometrists is associated with lower prices, controlling for quality differences. Prices are approximately 26.3-33.1 percent lower in markets in which price or nonprice media advertising by optometrists is observed. This is consistent with the FTC's finding that the average price charged for eyeglasses and eye examinations is $\$ 23.74$ lower in markets in which price advertising and chain optical firms are observed. ${ }^{49}$ The coefficient on the optician-to-population ratio is also negative and statistically significant in all regressions. Further, in all five regressions more rigorous licensing examinations, higher per capita income, and higher input costs are associated with higher prices, controlling for quality differences. For example, a 1 percent increase in the number of subject areas that must be covered in the state licensing examination results in a $0.17-0.37$ percent increase in price.

Table 5 reports the results of ordinary least squares regressions that test the effects of the commercial practice restrictions on quality, measured as the thoroughness of the eye examination. The results suggest that quality is not affected by the presence of the commercial practice restrictions. In the first quality regression the sum of the coefficients of the commercial practice restrictions is -17.8 percent, which is not significantly different from zero at the 1 percent level $(F=2.04)$. The summed coefficients of the commercial practice restrictions in the second quality regression equal -14.6 percent, again not statistically significant at the 1 percent level $(F=2.29)$. The results do not support the argument made by propo-

${ }^{49}$ Federal Trade Commission, supra note 5, at 4. 
nents of the commercial practice restrictions that the restrictions will increase the quality of ophthalmic services.

\section{Conclusions}

In 1977 the four commercial practice restrictions appear to have increased the price of an eye examination and pair of eyeglasses by at least 5-13 percent, holding quality constant, measured as the thoroughness of the eye examination and accuracy of the eyeglass prescription. And to reiterate, the commercial practice restrictions did not appear to increase the quality of ophthalmic services. These results provide support for the economic theory of regulation and for a recent extension of the economic theory of regulation, that subgroups of firms within an industry will use the regulatory process to increase their rivals' costs and, therefore, their own market power.

Consumers paid at least $\$ 4.7$ million more for eye examinations and eyeglasses in 1977 because of the four commercial practice restrictions. ${ }^{50}$ Further, part of this $\$ 4.7$ million is a social cost rather than an income transfer. Regulation-induced inefficiencies in production account for some of the price increase. The four commercial practice restrictions may inhibit optometrists' potential to realize economies of scale, the employment restriction may inhibit nonprofessional optical firms' potential to realize economies of scope, and the branch office restriction may prevent optometrists from employing the cost-minimizing combination of inputs. Also the opportunity costs of resources used by optometrists to influence the political process to attain market power through commercial practice laws and regulations are social costs. ${ }^{51}$

This paper suggests that commercial practice restrictions in the ophthalmic market are not protecting the consumer. The commercial practice restrictions increase price and have a statistically insignificant effect on quality. Intervention strategies should correct the market failure without causing serious distortions that lead to even greater consumer injury.

50 This estimate is based on the four restrictions increasing price by $\$ 19$, each optometrist providing 1,422 eye examinations and pairs of eyeglasses a year, American Optometric Association News, August 1, 1981; 18,589 optometrists practicing in states with trade name restrictions, 10,844 optometrists practicing in states with branch office restrictions, $\mathbf{8 , 6 1 3}$ optometrists practicing in states with location restrictions, and 14,750 optometrists practicing in states with employment restrictions, letter from Farrell Aron, Director of Statistical Research, American Optometric Association, September 15, 1982.

$s_{1} \rightarrow$ Richard A. Posner, The Social Costs of Monopoly and Regulation, 83 J. Pol. Econ. 807 (1975). 


\section{BIBLIOGRAPHY}

Akerlof, George A. "The Market for 'Lemons': Quality Uncertainty and the Market Mechanism.' Quarterly Journal of Economics 84 (August 1970): 488500 .

Begun, James W. Professionalism and the Public Interest: Price and Quality in Optometry. Cambridge, Mass.: MIT Press, 1980.

Begun, J.; Crowe, E.; and Feldman, R. "'Occupational Regulation in the States: A Causal Model.' Journal of Health, Politics, Policy, and Law 6 (Summer 1981): 229-54.

Benham, Lee. "The Effect of Advertising on the Price of Eyeglasses." Journal of Law and Economics 15 (October 1972): 337-52.

Benham, L., and Benham, A. " Regulating through the Professions: A Perspective on Information Control.' Journal of Law and Economics 18 (October 1975): 421-47.

Benham, L.; Maurizi, A.; and Reder, M. W. "Migration, Location and Remuneration of Medical Personnel: Physicians and Dentists." Review of Economics and Statistics 50 (August 1968): 332-47.

Blue Book of Optometrists. Chicago: Professional Press, Inc., 1978.

Caves, R. E., and Porter, M. E. "From Entry Barriers to Mobility Barriers: Conjectural Decisions and Contrived Deterrence to New Competition." Quarterly Journal of Economics 91 (May 1977): 421-41.

Coblens, Seymour L. Optometry and the Law. St. Louis: American Optometry Association, 1976.

Council of State Governments. Health Licensure Boards: Public Membership. Lexington, Ky.: Council of State Governments, June 1981.

DeVany, Arthur S.; Gramm, Wendy L.; Saving, Thomas R.; and Smithson, Charles W. "The Impact of Input Regulation: The Case of the U.S. Dental Industry.' Journal of Law and Economics 25 (October 1982): 367-81.

Federal Trade Commission. Staff Report on Advertising of Ophthalmic Goods and Services and Proposed Trade Regulation Rule (16 CFR Part 456). Washington, D.C.: Government Printing Office, May 1977.

Federal Trade Commission. State Restrictions on Vision Care Providers: The Effects on Consumers ("Eyeglasses II'). Washington, D.C.: Government Printing Office, July 1980.

Federal Trade Commission. Effects of Restrictions on Advertising and Commercial Practice in the Professions: The Case of Optometry. Washington, D.C.: Government Printing Office, September 1980.

Feldman, R., and Begun, J. W. "The Effects of Advertising: Lessons from Optometry.' Journal of Human Resources 13, Suppl. (1978): 247-62.

Frech, H. E., III. "Occupational Licensure and Health Care Productivity: The Issues and the Literature.' In Health Manpower and Productivity: The Literature and Required Future Research, edited by John Rafferty. Lexington, Mass.: Lexington Books, 1974.

Kihlstrom, R. E., and Riodan, M. H. "Advertising as a Signal." Journal of Political Economy 92 (1984): 427-50. 
$\rightarrow$ Kwoka, John. "Advertising and the Price and Quality of Optometric Services." American Economic Review 74 (March 1984): 211-16.

Leland, H. E. "Quacks, Lemons, and Licensing: A Theory of Minimum Quality Standards." Journal of Political Economy 87 (1979): 1328-46.

Maddala, G. S. Econometrics. New York: McGraw-Hill Book Co., 1977.

Maloney, Michael T., and McCormick, Robert E. "A Positive Theory of Environmental Quality Regulation.' Journal of Law and Economics 25 (April 1982): 99-123.

Meltzer, Alfred; Langwell, Kathryn; Keane, Michael; and Nelson, Shelly. "Report on the Geographic Distribution of Vision Care Providers.' Unpublished report. Silver Spring, Md.: Applied Management Sciences, Inc., 1983.

Nelson, Phillip. “Advertising as Information." Journal of Political Economy 81 (July/August 1974): 729-54.

Newman, Howard H. " Strategic Groups and the Structure-Performance Relationship." Review of Economics and Statistics 60 (August 1978): 417-25.

Oster, Sharon. "The Strategic Use of Regulatory Investment by Industry Subgroups." Economic Inquiry 20 (October 1982): 604-18.

$\rightarrow$ Pauly, Mark V., and Satterthwaite, Mark A. "The Pricing of Primary Care Physicians' Services: A Test of the Role of Consumer Information.' Bell Journal of Economics 12 (Autumn 1981): 488-506.

$\rightarrow$ Peltzman, S. "Toward a More General Theory of Regulation.' Journal of Law and Economics 19 (August 1976): 211-40.

Porter, Michael E. “The Structure within Industries and Companies' Performance.' Review of Economics and Statistics 61 (May 1979): 214-27.

$\rightarrow$ Posner, Richard A. "Theories of Economic Regulation." Bell Journal of Economics and Management Science 5 (Autumn 1974): 335-58.

$\rightarrow$ Posner, Richard A. "The Social Costs of Monopoly and Regulation." Journal of Political Economy 83 (1975): 807-27.

Salop, Steven. "Information and Monopolistic Competition." American Economic Review 66 (May 1976): 240-45.

$\rightarrow$ Salop, Steven C., and Scheffman, David T. "Raising Rivals' Costs." American Economic Review 73 (May 1983): 267-71.

$\rightarrow$ Schmalensee, Richard. "A Model of Advertising and Product Quality." Journal of Political Economy 86 (1978): 485-503.

Smallwood, Dennis E., and Conlisk, John. "Product Quality in Markets Where Consumers Are Imperfectly Informed.' Quarterly Journal of Economics 93 (February 1979): 1-23.

$\rightarrow$ Stigler, George J. "The Theory of Economic Regulation.' Bell Journal of Economics and Management Science 2 (Spring 1971): 3-21.

Stuart, Charles. "Consumer Protection in Markets with Informationally Weak Buyers.' Bell Journal of Economics 12 (Autumn 1981): 562-73.

U.S. Department of Commerce. Bureau of Economic Analysis. Survey of Current Business. Vol. 61. Washington, D.C.: Government Printing Office, April 1981.

U.S. Department of Commerce. Bureau of the Census. State and Metropolitan Area Data Book. Washington, D.C.: Government Printing Office, 1979. 
U.S. Department of Health, Education, and Welfare. National Center for Health Statistics. Opticians Employed in the Health Services, U.S., 1968. Ser. 14, No. 3. DHEW Publication No. (HSM) 72-1052. Washington, D.C.: Government Printing Office, 1972.

U.S. Department of Health, Education, and Welfare. Public Health Service. Bureau of Health Manpower. Report to the Congress: Reimbursement under Part B of Medicare for Certain Services Provided by Optometrists. Rockville, Md.: U.S. Department of Health, Education, and Welfare, Bureau of Health Manpower, July 1976.

U.S. Department of Health, Education, and Welfare. Bureau of Health Manpower. Supply of Optometrists in the United States, Current and Future. DHEW Publication No. (HRA) 79-18. Hyattsville, Md.: U.S. Department of Health, Education, and Welfare, Bureau of Health Manpower, October 1978.

Waterson, Michael. Economic Theory of Industry. Cambridge: Cambridge University Press, 1984. 